\title{
PROFIL EMPATI MAHASISWA ETNIS JAWA (Survei Yang Dilakukan Pada Mahasiswa Jurusan Bimbingan Dan Konseling Universitas di DKI Jakarta)
}

\author{
Pemi Senja Maulana ${ }^{1}$ \\ Dra. Michiko Mamesah, M.Psi \\ Happy Karlina Marjo, M.Pd., Kons ${ }^{3}$
}

\begin{abstract}
The porpuse of this research was to find out description aboutthebasicempathy's students college of Guidance and Counselingfrom Java ethnic in DKI Jakarta. This research used a descriptive study with 112 respondent of students college of Guidance and Counselingfrom5UniversitiesinJakarta; Universitas Negeri Jakarta (UNJ), Universitas Muhammadiyah Prof.DrHamka Jakarta (UHAMKA), Universitas IslamAs-Syafi'iyah Jakarta, Universitas Atma Jaya and Universitas Kristen Indonesia (UKI). The research instrument used Basic Empathy Scale (BES) from Darrick Jollife dan David P Farrington (2006) with $r$ 0.857. The valid and reliability test used SPSS version 17.0. The Valid test from 20 statements there were 17 valid statements and 3 statements are drop. The drop statements rechanged to be a new editorial statements. The reliability test obtained 0,803 which means it very high reliability and the basic empathy scale can be trust.. This study has found condition of emphaty of students counseling in Jakarta at the high level categoryof 53,57\%, middle category of $46,43 \%$, and $0 \%$ lower. From these findings that there are students at middle level category, these need to improvement and development of empathy students' condition such as using audiovisual media (movie) or roleplay method in guding service
\end{abstract}

Keyword: Empathy, Students College Guidance and Counseling, Java Ethnic

\section{Pendahuluan}

Provinsi DKI Jakarta sudah menjadi tempat tinggal penduduk multietnis. Data menunjukkan, bukan lagi etnis Betawi yang mendominasi Jakarta, namun justru etnis lain yang berasal dari luar kota tersebut juga mulai menghuni dan bahkan mendominasi seperti data yang ditunjukkan oleh sensus penduduk pada tahun 2009 terdapat 6 besar etnis yang menduduki Jakarta yaitu etnis Jawa, Betawi Sunda, Minang, Batak, dan Tionghoa.

Heterogenitas dan keberagaman etnis yang bera- da di Jakarta bisa saja menyebabkan konflik tentunya disebabkan memiliki nilai dan norma serta adat yang dijunjung dan dipegang teguh sebagai pedoman hidup sekaligus menunjukkan ciri kekhasan identitas budayanya masing-masing. Perbedaan nilai, norma dan adat yang bertentangan antara budaya yang satu dan yang lainnya dapat memicu stereotipe etnis dan konflik.

Pandangan negatif muncul sebagai representasi stereotipe etnis yang terjadi pada etnis lain mengenai etnis Jawa, misalnya orang Batak memandang

1 Mahasiswa Jurusan Bimbingan dan Konseling FIP UNJ, pemisenjamaulana@gmail.com

2 Dosen Bimbingan dan Konseling FIP UNJ, michikomamesah@yahoo.com

3 Dosen Bimbingan dan Konseling FIP UNJ, happykarlina.unj2005@gmail.com 
orang Jawa sebagai orang yang munafik dan tidak berterus terang, karena orang Jawa tidak menunjukkan perasaaan yang sebenarnya dalam keadaan tertentu. Stereotipe lainnya yang didapatkan melalui wawancara tidak terstruktur mengenai pandangan negatif terhadap orang Jawa adalah pelit atau kikir. Berdasarkan penjelasan para responden, sifat kikir ditunjukkan melalui pergaulan sehari-hari misalnya, tidak memberi saat makan atau minum kepada temannya dan sangat perhitungan dengan permasalahan uang serta memaknai hemat dengan "terlalu hemat".

Interaksi yang terjadi pada setiap individu yang berlatar multietnis pun tentu mengalami gesekan, konflik dan stereotipe. Stereotipe dan konflik yang terjadi juga sebenarnya dapat dicegah dan diatasi dengan melakukan penyesuaian atau adapatasi antaretnis.Adaptasi dan interaksi tidak terlepas dari membangun rapport melalui komunikasi dan empati. Empati dan komunikasi digunakan untuk memahami perasaan dan mengkomunikasikan setiap permasalahan yang ada sehingga setiap orang yang memiliki empati dan komunikasi yang baik dapat memahami perasaan dan mampu menempatkan diri dalam posisi diri orang lain serta mampu mengkomunikasikan setiap hal kepada orang lain dengan tanpa terpengaruh stereotipe. Bahkan dalam bimbingan dan konseling empati dipelajari lebih mendalam. Empati digunakan sebagai radar untuk mendeteksi perasaan orang lain yang kemudian konselor dapat memahami perasaan konseli dan menempatkan posisi diri pada keadaan konseli.

Empati juga dianggap sebagai salah satu modal utama dalam melaksanakan tugas sebagai konselor. Dengan modal empati, konselor dapat mengarahkan komunikasi yang lebih mendalam dan memiliki kontribusi besar dalam berkonseling misalnya, konseli merasa sangat sedih.Dengan empati, konselor dalam memahami perasaan sedih dan menempatkan posisi diri konselor dalam suasana sedih serta dapat menyikapi perasaan konseli tersebut.

Tentu saja, empati dan komunikasi menjadi dua hal yang digunakan sebagai modal utama dalam melaksanakan tugas sebagai konselor, sehingga pengembangan kemampuan empati dan komunikasi harus dilakukan sebelum menjadi seorang konselor. Tidak lain, pengembangan kemampuan empa- ti dan komunikasi dilaksanakan pada masa pendidikan di perguruan tinggi. memang pengembangan kemampuan empati dan komunikasi bisa dilakukan kapan dan dimana saja. Namun, lembaga perguruan tinggi dalam hal ini jurusan Bimbingan dan Konseling merupakan satu lembaga formal yang secara hukum diperbolehkan untuk mencetak lulusannya sebagai konselor. Oleh karena itu, pada masa pendidikan di perguruan tinggi, empati dan komunikasi mahasiswa jurusan Bimbingan dan Konseling perlu ditingkatkan dan dikembangkan sebagai modal untuk melaksanakan tugas sebagai konselor di kemudian hari.

Berdasarkan paparan di atas mengenai empati sebagai seorang calon konselor, peneliti tertarik untuk membuat gambaran empati mahasiswa Bimbingan dan Konseling Universitas di DKI Jakarta khususnya bagi mahasiswa yang berlatar belakang etnis Jawa.

\section{Kajian Teori \\ 1. Empati \\ Definisi Empati}

Goleman (Dwi Nur Rachmah, 2014:52) mendefinisikan empati sebagai kemampuan untuk mengetahui bagaimana perasaan orang lain. Empati (Egan, 2002:48) juga ditempatkan sebagai "jantung dari kecerdasan emosional" yang menjadi "radar sosial" seseorang dalam merasakan perasaaan dan perspektif orang lain. Egan (Pedersen, dkk, 2008:11) mendeskripsikan empati sebagai keterampilan komunikasi interpersonal di mana konselor berusaha untuk memahami konseli, dan mengkomunikasikan pemahamannya dengan tujuan membantu konseli lebih memahami dirinya sendiri.

Dalam pengembangan Skala Dasar Empati atau Basic Empathy Scale yang dikembangkan oleh Darrick Jolliffe\& David P Farrington (2006:59), empati dikategorisasikan menjadi dua, yaitu: empati kognitif, dan empati afektif. Empati kognitif adalah pemahaman pada emosi orang lain, sedangkan empati afektif didefinisikan keselarasan afektif pada keadaan emosi orang lain. Hal di atas diadopsi dari Cohen and Strayer (Jolliffe\&Farrington, 2006: 59) yang mendefinisikan empati sebagai berikut: Empathy defined as the understanding and sharing in another's emotional state or context. 
Pendapat serupa dikemukakan oleh Dwi Nur Rachmah (2014:52), empati merupakan salah satu elemen dasar dalam suatu hubungan, yang digambarkan sebagai konstruk multidimensi yang melibatkan komponen kognitif dan afektif.

Berdasarkan beberapa definisi sebelumnya, empati disimpulkan sebagai kemampuan memahami perasaan orang lain (aspek kognitif), menempatkan posisi diri pada perasaan dan konteks orang lain (aspek afektif) yang harus dimiliki seorang konselor untuk melaksanakan tugas sebagai penyedia layanan bimbingan dan konseling yang profesional.

\section{Aspek Empati}

Menurut Cohen dan Strayer (Jolliffe\&Farrington, 2006: 59), bahwa dalam proses individu berempati melibatkan aspek afektif dan kognitif.

\section{Aspek afektif :}

Aspek afektif merupakan kecenderungan seseorang untuk mengalami perasaan emosional orang lain yaitu ikut merasakan ketika orang lain merasa sedih, menangis, kecewa, dan keadaam emosi orang lain.

\section{Aspek kognitif :}

Aspek kognitif dalam empati difokuskan pada proses intelektual untuk memahami keadaan emosi atau perasaan orang lain dengan tepat dan menerima pandangan mereka, misalnya membayangkan perasaan orang lain ketika marah, kecewa, senang, memahami keadaan orang lain.

\section{Etnis Jawa}

Kelompok etnis atau suku bangsa (wikipedia:http://id.wikipedia.org/wiki/Kelompok_etnis) adalah suatu golongan manusia yang anggota-anggotanya mengidentifikasikan dirinya dengan sesamanya, biasanya berdasarkan garis keturunan yang dianggap sama. Identitas suku ditandai oleh pengakuan dari orang lain akan ciri khas kelompok tersebut seperti kesamaan budaya, bahasa, agama, perilaku, dan ciri-ciri biologis.

Etnis Jawa (Koentjaraningrat, 2004:329-330) adalah etnis bangsa Indonesia yang paling banyak jumlahnya, yang berasal dari seluruh daerah Jawa
Tengah, Jawa Timur dan sebagian Jawa Barat, yang menggunakan bahasa Jawa secara keseluruhan, hanya saja terdapat perbedaan dialek di daerah tertentu.

Sistem keturunan juga memiliki kontribusi dalam mewariskan etnis yang dimiliki seorang anak dari ayah dan ibunya. Oemar salim (2000:2) mengungkapkan bahwa Etnis Jawa merupakan etnis yang menarik garis keturunan berdasarkan sistem parental atau bilateral yakni dari Ayah dan Ibu. Sehingga, peneliti mengambil reponden penelitian berdasarkan penjelasan ini, dikarenakan hal ini yang paling memungkinkan dalam menentukan seseorang beretnis Jawa yang tidak berada pada domisili aslinya.

\section{Karakteristik Mahasiswa Bimbingan dan Konseling}

Mahasiswa (UURI No 12 Tahun 2012 Bab 1 Pasal 1 ayat 15) adalah peserta didik pada jenjang Perguruan Tinggi.Menurut Pusat Bahasa Indonesia DEPDIKNAS RI yang memberikan akses KBBI Online, Mahasiswa didefinisikan sebagai orang yang belajar di Perguruan Tinggi.Berdasarkan definisi di atas, peneliti menyimpulkan bahwa mahasiswa adalah seseorang atau lebih yang dikategorikan peserta didik yang sedang belajar di Perguruan Tinggi.

Mahasiswa Bimbingan dan Konseling adalah mahasiswa yang belajar di Jurusan Bimbingan dan Konseling yang kelak menjadi seorang konselor atau guru Bimbingan dan Konseling.

\section{Metode Penelitian}

Penelitian ini bertujuan untuk melihat profil empati mahasiswa Bimbingan dan Konseling etnis Jawa Universitas di DKI Jakarta. Penelitian ini merupakan studi survei yang menggunakan metode deskriptif kuantitatif. Responden penelitian berjumlah 112 mahasiswa Bimbingan dan Konseling etnis Jawa yang berasal dari 5 Universitas, yaitu: Universitas Negeri Jakarta, Universitas Muhammadiyah Prof. DR. Hamka, Universitas Islam Assafi'iyah, Universitas Katolik Atmajaya dan Universitas Kristen Indonesia. Penentuan sampel dalam penelitian ini didasarkan pada kriteria dibawah ini, yaitu: a) Beretnis Jawa dilihat berdasarkan sistem keturunan parental atau bilateral, b) Berusia 18-24 tahun, c) 
Terdaftar sebagai mahasiswa Bimbingan dan Konseling di salah satu perguruan tinggi yang dipaparkan di atas.

Definisi konseptual variabel penelitian ini diambil dari Basic Empathy Scale (BES) didasarkan khusus pada definisi empati oleh Darrick Jollife dan David P. Farrington yang diadopsi dari teori Cohen dan Strayer yakni empati didefinisikan sebagai penempatan posisi diri sendiri pada keadaaan emosi seseorang yakni sedih, bahagia, takut dan marah (empati afektif) dan pemahaman seseorang pada keadaan emosi orang tersebut (empati kognitif).

Empati yang diukur dalam skala ini diformulasikan menjadi dua aspek yaitu empati kognitif dan empati afektif.

\section{Empati Kognitif}

Empati Kognitif menunjukkan pada kemampuan memahami keadaan atau konteks perasaaan seseorang yang digambarkan dalam 4 emosi dasar manusia, yaitu sedih, bahagia, takut dan marah.

\section{Empati Afektif}

Empati afektif menunjukkan pada kemampuan seseorang dalam menempatkan posisi diri pada keadaan atau konteks perasaan orang lain yang tergambarkan dalam 4 emosi dasar, yakni sedih, bahagia, takut dan marah.

Isntrumen yang digunakan dalam penelitian ini menggunakan Skala Baku Basic Emphaty Scale (BES) yang diadaptasi dan disesuai dengan karakteristik dan adat budaya Indonesia. Uji keterbacaaan yang dilakukan oleh Dosen S3 Universitas Pendidikan Indonesia Bandung yaitu Prof. Dr. Syamsu Yusuf, M.Pd., Dr. Tina Hayati Dahlan, M.Pd.Psi., Prof. Dr. Ahman. Skala yang digunakan dalam penelitian menggunakan model skala likert 1-5 dengan pernyataan "Sangat Tidak Setuju" hingga "Sangat Setuju". Setelah di uji reliabilitas terdapat 3 butir pernyataan yang drop, tetapi akhirnya peneliti memperbaiki redaksi dan uji reliabilitas menunjukkan angka sebesar 0.803 . Teknik analisis data menggunakan tiga klasifikasi yakni ditentukan dengan:
Tinggi
$\mathrm{X} \geq \mu+\mathrm{SD}$
Sedang
$\mu+\mathrm{SD}<\mathrm{X} \geq \mu-\mathrm{SD}$
Rendah
$\mathrm{X}<\mu-\mathrm{SD}$

Keterangan :

$\mathrm{X}=$ Skor yang didapat

$\mu=$ Mean teroritis (jumlah butir item $\mathrm{x}$ skor tengah butir)

$\mathrm{SD}=$ Standar Deviasi $(1 / 6 \mathrm{x}$ (skor maksimal - skor minimal)

\section{Hasil dan Pembahasan}

Persetase data empati keseluruhan mahasiswa Bimbingan dan Konseling etnis Jawa yakni sebagai berikut:

\begin{tabular}{|c|c|c|c|c|c|}
\hline \multirow{2}{*}{$\begin{array}{c}\text { Kriteria } \\
\text { Nilai }\end{array}$} & \multirow{2}{*}{ Klasifikasi } & \multicolumn{4}{|c|}{ Empati Mahasiswa BK Keseluruhan } \\
\cline { 3 - 6 } & $\begin{array}{c}\text { Laki- } \\
\text { laki }\end{array}$ & Persentase & Perempuan & Persentase \\
\hline$\geq \mathbf{7 3}$ & Tinggi & 6 & $40 \%$ & 54 & $55,67 \%$ \\
\hline $\mathbf{4 7 - 7 2}$ & Sedang & 9 & $60 \%$ & 43 & $44,33 \%$ \\
\hline$<\mathbf{4 7}$ & Rendah & 0 & $0 \%$ & 0 & $0, \%$ \\
\hline \multicolumn{2}{|c|}{ Total } & 15 & $100 \%$ & 97 & $100 \%$ \\
\hline
\end{tabular}

Berdasarkan hasil pengolahan, data menunjukkan bahwa terdapat 60 mahasiswa Bimbingan dan Konseling etnis Jawa terdiri dari 6 laki-laki dan 54 perempuan yang termasuk klasifikasi tinggi atau sama dengan 53,57\% dari jumlah keseluruhan. Bersandar pada teori Cohen dan Strayer (Jollife dan Farrington, 2006:592-593) mengenai empati yang didefinisikan sebagai pemahaman mengenai perasaan seseorang (aspek kognitif) dan menempatkan posisi diri sendiri pada perasaan orang tersebut (aspek afektif), dapat dikatakan bahwa 60 mahasiswa Bimbingan dan Konseling etnis Jawa di DKI Jakarta sudah sangat mampu memahami perasaan orang lain dan menempatkan diri sendiri pada keadaan dan perasaan orang lain tersebut. Selanjutnya mahasiswa Bimbingan dan Konseling yang berada pada klasifikasi sedang dalam empati mencapai 46,43\% dari jumlah keseluruhan responden 112 mahasiswa yaitu setara dengan 52 mahasiswa. Mahasiswa pada klasifikasi sedang yakni sejumlah 52 mahasiswa tersebut yang terdiri 9 laki-laki dan 43 perempuan cu-kup mampu memahami dan menempatkan diri sendiri pada keadaan perasaan orang lain. Namun, pada klasifikasi rendah, tidak ada satu mahasiswa pun yang memiliki empati pada klasifikasi ini. Dapat disimpulkan bahwa sebagian besar mahasiswa sudah memiliki empati yang mumpuni dan berklasifikasi tinggi terutama mahasiswa 
perempuan sedangkan mahasiswa laki-laki sebagian besar berada pada klasifikasi sedang.

Memperjelas perbedaan empati mahasiswa BK etnis Jawa antara laki-laki dan perempuan, peneliti membandingkan skor rerata empati mahasiswa laki-laki dan perempuan yang tergambarkan dalam tabel berikut:

\begin{tabular}{|c|c|c|}
\hline \multirow{2}{*}{ Variabel } & \multicolumn{2}{|c|}{ Skor Rerata Empati } \\
\cline { 2 - 3 } & $\begin{array}{c}\text { X Mahasiswa } \\
\text { Laki-laki }\end{array}$ & $\begin{array}{c}\text { X Mahasiswa } \\
\text { Perempuan }\end{array}$ \\
\hline \multirow{2}{*}{ Empati } & $\begin{array}{c}68.67 \\
\text { Sedang }\end{array}$ & $\begin{array}{c}73.64 \\
\text { Tinggi }\end{array}$ \\
\hline
\end{tabular}

Berdasarkan hasil tersebut data menunjukkan rerata skor empati mahasiswa etnis Jawa laki-laki berada pada klasifikasi sedang, sedangkan skor rerata mahasiswa perempuan berada pada klasifikasi tinggi. Skor rerata mahasiswa perempuan lebih besar dibandingkan skor rerata mahasiswa laki-laki. Skor rerata empati mahasiswa perempuan etnis Jawa yaitu sebesar 73,64 dan untuk skor rerata mahasiswa laki-laki sebesar 68,67. Dapat disimpulkan bahwa empati mahasiswa peremuan lebih besar dibandingkan mahasiswa laki-laki.

Temuan hasil penelitian ini sangat sesuai dengan penjelasan Sari dkk (2003:84) bahwa empati adalah kemampuan individu untuk menempatkan diri dalam memahami kondisi atau keadaan pikiran, sifat serta perasaan orang lain, mengendalikan diri, ramah, dan humanis. Etnis Jawa yang sebelumnya dikatakan oleh Schweizer (Mulyana dan Jalaludin Rahmat, 2005:215-230) memiliki ciri "halus pembawaan", "ramah-tamah", dan "sopan santun" sehingga tidak mengherankan empati mahasiswa BK etnis Jawa memiliki kecenderungan berklasifikasi tinggi.

Berbeda dengan temuan hasil penelitian yang dilakukan Fathur Rahman (2006:7) mengenai empati mahasiswa Bimbingan dan Konseling di Universitas Negeri Yogyakarta yang sebagian besar berada pada klasifikasi sedang. Perbedaan ini dapat disebabkan oleh beberapa faktor, salah satunya adalah pengkategorisasian klasifikasi nilai empati.

Penelitian yang dilakukan Fathur Rahman menggunakan rumus mean empirik dalam mengkategorisasikan empati mahasiswa Bimbingan dan Konseling di UNY, sedangkan penelitian ini menggunakan rumus mean teoritis. Peneliti menganggap rumus mean teoritis sangat tepat digunakan untuk mengklasifikasikan empati dalam penelitian ini, karena rumus mean teoritis melihat empati berdasarkan norma rerata instrumen bukan pada rerata skor yang didapatkan kelompok. Selain hal tersebut, terdapat kemungkinan disebabkan juga oleh faktor-faktor yang mempengaruhi empati menurut Indrayani (Ernainy, 2008:16-17) yakni pola asuh, jenis kelamin, situasi, pengalaman dan objek respon, usia, sosialisasi. Dalam hal ini peneliti berasumsi bahwa etnis individu juga dapat dipertimbangkan sebagai salah satu faktor yang mempengaruhi empati, karena etnis terkait dengan faktor situasi, pengalaman dan objek respon serta sosialisasi yang paparkan oleh Indrayani.

Selanjutnya, untuk menindak lanjuti mahasiswa yang berklasifikasi sedang perlu diadakan program pengembangan empati yakni dengan melakukan bimbingan menggunakan metode role playing atau juga media audio visual (film). Karena dengan program bimbingan menggunakan metode role playing (bermain peran) pada penelitian yang dilakukan oleh Krisan Andreas Pramuaji (2012) terbukti meningkatkan empati. Begitu juga bimbingan menggunkan media film terbukti dapat meningkatkan empati sesuai dengan hasil penelitian yang dilakukan oleh Anis Fidiyaningrum (2006). Selain itu, jika memang proram pengembangan yang sudah ada, diharapkan program tersebut selalu dievaluasi dan diperbaharui seperti praktik mandiri konseling dan PPL (Program Pengalaman Lapangan).

Deskripsi data per universitas tidak jauh berbeda dengan pembahasan sebelumnya, Pembahasan ini memberikan terjabarkan dalam tabel di bawah, yakni sebagai berikut:

\begin{tabular}{|c|c|c|c|c|c|c|}
\hline \multirow{2}{*}{$\begin{array}{c}\text { Kriteria } \\
\text { Nilai }\end{array}$} & \multirow{2}{*}{ Klasifikasi } & \multicolumn{5}{|c|}{ Empati Mahasiswa } \\
\cline { 3 - 7 } & & UNJ & UHAMKA & UIA & UKI & $\begin{array}{c}\text { UNIKA } \\
\text { Atmajaya }\end{array}$ \\
\hline $\mathbf{2 7 3}$ & Tinggi & 19 & 19 & 6 & 3 & 13 \\
\hline $\mathbf{4 7 - 7 2}$ & Sedang & 23 & 10 & 5 & 1 & 13 \\
\hline$<\mathbf{4 7}$ & Rendah & 0 & 0 & 0 & 0 & 0 \\
\hline
\end{tabular}

Berdasarkan hasil pengolahan didapatkan bahwa sebaian besar mahasiswa BK etnis Jawa tiga universitas memiliki empati pada klasifikasi tinggi yakni Universitas Muhammadiyah Prof Dr. Hamka, Universitas Islam Assyfi'iyah dan Universitas Kris- 
ten Indonesia, sedangkan Universitas Negeri Jakarta dan Universitas Katolik Atmajaya sebagian besar empati mahasiswanya berada klasifikasi sedang, tetapi mahasiswa yang memiliki empati pada klasifikasi tinggi pada dua Universitas ini juga tidak sedikit, seperti yang ditunjukan tabel di atas yakni 19 dari 42 mahasiswa UNJ etnis Jawa berada pada klasifikasi tinggi dan setengah dari jumlah mahasiswa etnis Jawa di UNIKA Atmajaya pun berada pada klasifikasi tinggi. Namun temuan yang menarik adalah tidak adanya satu mahasiswa pun yang memiliki empati pada klasifikasi rendah.

Selanjutnya untuk melihat perbandingan aspek yang lebih dominan dalam profil empati mahasiswa etnis jawa dari setiap universitas, peneliti menampilkan tabel di bawah:

\begin{tabular}{|l|c|c|c|c|}
\hline \multirow{2}{*}{ Instansi } & \multicolumn{2}{|c|}{ Aspek Kognitif } & \multicolumn{2}{c|}{ Aspek Afektif } \\
\cline { 2 - 5 } & $\begin{array}{c}\text { Skor } \\
\text { rerata }\end{array}$ & Persentase & $\begin{array}{c}\text { Skor } \\
\text { rerata }\end{array}$ & Persentase \\
\hline UNJ & 34,50 & $77 \%$ & 37,19 & $68 \%$ \\
\hline UHAMKA & 34,90 & $78 \%$ & 39,93 & $73 \%$ \\
\hline UKI & 34,25 & $76 \%$ & 39,75 & $72 \%$ \\
\hline UNIKA & 34,35 & $76 \%$ & 37,50 & $68 \%$ \\
\hline UIA & 35,82 & $80 \%$ & 39,45 & $72 \%$ \\
\hline
\end{tabular}

Aspek yang paling mendominasi empati mahasiswa Bimbingan dan Konseling etnis Jawa keseluruhan Universitas di DKI Jakarta adalah aspek kognitif.Hal ini terlihat dari persentase aspek empati diatas yakni keseluruhan Universitas di DKI memiliki persentase yang lebih besar pada aspek kognitif dibandingkan aspek afektif. Merujuk pada definisi teorinya mengenai empati dapat disimpulkan bahwa mahasiswa Bimbingan dan Konseling etnis Jawa pada 5 Universitas tersebut lebih sangat mudah memahami perasaan orang lain dibandingkan merasakannya.

Universitas yang dirasa sudah memiliki empati baik kognitif maupun afektif yang sudah sangat baik adalah Universitas Islam Assyafi'iyah dan Universitas Muhammadiyah Prof. Dr. Hamka, sedang Universitas Negeri Jakarta, Universitas Kristes Indonesia dan Universitas Katolik Atmajaya masih menunjukkan empati yang tergolong sedang pada aspek afektif.

Merujuk pada penelitian Duan dan Hill (Ernainy, 2008: 19) mengenai proses terjadinya empati, dapat dikatakan bahwa UIA dan UHAMKA sudah berada pada proses yang meliputi kognitif dan afektif yakni ditunjukkan dengan kedua aspek tersebut berada klasifikasi tinggi, sedangkan UNJ, UKI dan UNIKA Atmajaya masih berada pada proses kognitif, yakni hal ini dilihat dari klasifikasi empati pada aspek afektif masih tergolong sedang.

Asumsi peneliti mengenai alasan didapatkannya hasil empati kognitif lebih dominan dibandingkan afektif merujuk pada penjelasan Duan dan Hill yakni proses empati yang terjadi sudah masuk pada proses kognitif-afektif, tetapi proses yang sebelumnya dilalui dengan hasil yang kurang maksimal terutama pada proses afektif. Proses afektif dirasa lebih sulit untuk dilalui, karena afektif atau emosi sangat berkaitan dengan keadaan psikologi misalnya mood, minat dan motivasi,serta keadaaan hubungan yang terjalin. Keadaan jasmani juga memiliki pengaruh dalam berprilaku empati baik kognitif maupun afektif, yakni dalam kondisi kesehatan yang kurang baik dapat menampilkan perilaku empati yang kurang maksimal terhadap orang lain.

\section{Kesimpulan dan Saran}

Berdasarkan hasil penelitian yang telah dilakukan mengenai empati mahasiswa Bimbingan dan Konseling etnis Jawa Universitas di DKI Jakarta dapat disimpulKan bahwa mayoritas empati mahasiswa Bimbingan dan Konseling etnis awa pada 5 Universitas di DKI Jakarta berada klasifikasi tinggi dapat dikatakan sebagian besar mahasiswa tersebut sangat mampu memahami dan menempatkan diri sendiri pada keadaan perasaan orang lain.

Namun, masih ada mahasiswa Bimbingan dan Konseling yang memiliki empati pada klasifikasi sedang sehingga dengan paparan hasil dalam penelitian ini dapat dijadikan dasar pengembangan kemampuan empati setiap mahasiswa Bimbingan dan Konseling.

\section{Daftar Pustaka}

Anis Fidiyaningrum, Upaya Meningkatkan Empati Mahasiswa dengan Memanfaatkan Media Bimbingan "Penelitian dilakukan pada mahasiswa Angkatan 2005 Jurusan Bimbingan dan Konseling Fakultas Ilmu Pendidikan Universitas Negeri Semarang Tahun Akademik 2005/2006”, (Semarang : Skripsi-UNS, 


\section{6)}

DarrickJolliffe\& David P Farrington, Basic Empathy Scale (England - Cambridge University, Institute of Criminology : Elsevier Ltd, 2006)

Dwi Nur Rachmah, EmpatiPada Pelaku Bullying, (Kalimantan : Jurnal Ecopsy, 2014)

Egan, Skilled Helper : A Problem Management and Opportunity-Development Aprroach to Healping (United State : Wadsworth Groups Book, 2002)

Fathur Rahman, Kualitas Empati dan Intensi Proposial Sebagai Dasar Kepribadian Konselor (Yogyakarta UNY: Jurnal Pendidikan dan Kebudayaan 2006)

Koentjaraningrat, Manusia dan Kebudayaan Di Indonesia, (Jakarta : Djambatan, 2004)

Krisan Andreas Pramuaji, Penggunaan Metode Bermain Peran Dalam Meningkatkan Empati Teman Sebaya Siswa Kelas XII D Jurusan Administrasi Perkantoran Di SMK PGRI 02 Salatiga, (Salatiga : Skripsi BK FKIP UKSW, 2012)
Mulyana dan jalaludin Rakhmat, Komunikasi Antarbudaya (Bandung : PT Remaja Rosdakarya, 2005)

Pedersen dkk, Inclusive CulturalEmpathy : Making Relationships Central in Counseling and Psycotherapy, (Washington D.C : American Psychological Association, 2008)

Undang-Undang Republik Indonesia No 12 Tahun 2012 Bab 1 Pasal 1 ayat 15 mengenai Mahasiswa

Wikipedia, Kelompok Etnis (http://id.wikipedia.org/wiki/Kelompok_etnis) diakses pada pukul 23.26 hari selasa tanggal 17 Juni 2014

Windy Ernainy, Empati Siswa Pada Kelas Akselerasi Dan Reguler, (Semarang : Fakultas Psikologi, Universitas Katolik Soegijaranata, 2008) 